\title{
Funding the growth of UK technology-based small firms since the financial crash: are there breakages in the finance escalator?
}

\section{Corresponding author:}

David North

CEEDR, Middlesex University Business School

The Burroughs, Hendon, London NW4 4BT

Tel: 02084115514

Email: d.north@mdx.ac.uk

\section{Co-authors:}

Robert Baldock

CEEDR, Middlesex University Business School

The Burroughs, Hendon, London NW4 4BT

Tel: 01508499177

Email: robbaldock@r-blegal.com

Farid Ullah

The Robert Gordon University

Aberdeen Business School

Garthdee Campus, Garthdee Road,

Aberdeen AB10 7QE

Email: f.ullah@rgu.ac.uk

\section{Abstract}

This paper presents recent research assessing the impact of the financial crisis on young and established Technology-Based Small Firms (TBSFs) and considers whether their ability to contribute to economic growth is being affected by ongoing problems in obtaining external finance. It reports on original findings from a survey of 100 TBSFs undertaken in late 2010 as well as 20 in-depth interviews with a range of finance providers. The surviving TBSFs exhibited considerable demand for external finance since 2007, particularly for working capital and early stage R\&D, sought mainly from banks, but also with younger TBSFs seeking business angel finance and innovation grants and more mature TBSFs seeking venture capital finance. However, both debt and equity finance have become harder to access for TBSFs, particularly for early stage funding and for more R\&D intensive firms, hampering their growth potential. Where external finance has been available, the terms and conditions set by providers were often unacceptable to business owners. The paper concludes that the smooth operation of the finance escalator has proved difficult to achieve under recent financial conditions and identifies a number of breakpoints relating to TBSFs which government policy needs to address. 


\section{Introduction}

It is generally accepted that a dynamic technology based small firm (TBSF) sector (1) is pivotal to enhancing entrepreneurship and innovation, leading to economic growth and the creation of new jobs (Siegel, Westhead and Wright 2003; NESTA 2009b). However, TBSFs face greater obstacles than conventional SMEs due to market failures which restrict key inputs, most notably finance (Murray and Lott 1995; Oakey 2003). For instance, Carpenter and Peterson (2002) argued that high-tech small firms are more likely to be financially constrained than other small firms because they suffer from finance market imperfections, thereby curtailing their contribution to economic growth. Moreover, evidence from a high-tech firms' survey in the UK (Westhead and Storey 1997) showed that it was those with 'the most sophisticated technologies' that faced continual financial constraints to the development of the business. More recent research also indicated that TBSF growth and development was being hindered by a shortage of external finance, notably the availability of relatively small amounts of equity finance (Pierrakis and Mason 2008). In view of previous evidence indicating access to external finance to be negatively affected by economic conditions (Bougheas, Mizena, and Yalcinb 2006) as well as recent surveys indicating the difficulties that SMEs have experienced in obtaining external finance since the onset of the credit crunch in 2007 (Cosh et al. 2009; Fraser 2009; IFF 2010), it seems reasonable to expect TBSFs to have been particularly adversely affected by the recent financial crisis. Indeed, it has been suggested that those small businesses most capable of creating new jobs and stimulating economic growth are being prevented from doing so by limited access to investment capital because lenders, particularly banks, ignore growth orientations and potential during recessionary periods (Cowling ,Liu, and Ledger 2012).

Given this context, this paper presents some evidence on the experiences of TBSFs in the UK on accessing external finance during the depressed market and tighter financial conditions that existed between 2007 and 2010. The research, undertaken in 2010-11, assesses the impact of the financial crisis on a sample of 100 TBSFs, examining their requirements for debt, equity and grant finance since 2007 and the extent to which this has been met from different external sources. A key underlying question is the extent to which the ability of both young and more established TBSFs to contribute to the UK's economic recovery is being held back by ongoing problems in obtaining the external finance needed for growth. Various characteristics relating to the sample of TBSFs are 
explored in order to consider the extent to which they exhibit demand for different forms of external finance and are able to access it. These include: trading age (distinguishing between younger and more established firms); sector (comparing bio/life-science and electronics/IT firms); business origin, with a focus on comparing spin outs (from universities, research institutes, or existing companies) and non-spin outs; and the stage of development for which finance was being sought (i.e. seed finance, early stage finance, later R\&D and commercialisation). In addition to this telephone interview survey of owner-managers of TBSFs, 20 interviews were conducted with a range of finance providers (including banks, business angels, public and private venture capital funds) in order to provide a supply-side perspective on the financing of TBSFs since the onset of the financial crisis.

\section{Theoretical context}

\section{Financing the growth of TBSFs}

In their seminal paper on the financing of small businesses, Berger and Udell (1998) explain how the financial needs and options of small firms change as they become 'less informationally opaque' to potential finance providers. A central tenet of their financial growth cycle model is that the interconnectedness and substitutability between different sources of finance is crucial to financing the continuous development of businesses, especially those that have high growth potential but are high risk. To illustrate this they give the examples of contracts between entrepreneurs and business angels being made in anticipation of future venture capital and debt finance from commercial banks being predicated on having sufficient equity from angel investors and venture capitalists to reduce the risks associated with information asymmetry. Because of the informational opacity of small businesses, Berger and Udell $(1998,651)$ go on to argue that small businesses "are likely to bear a disproportionate share of the loss of funding that occurs when there is market failure". Also, at times of financial distress and economic downturn, small businesses are likely to be especially vulnerable not only to banks reducing their credit risk exposure but also to the reduced flow of funds into business angel and venture capital equity markets coming from public equity (via an initial public offering (IPO)) and trade sales).

High risk SMEs, such as innovative TBSFs, are particularly likely to be adversely affected by finance market imperfections and funding gaps because of the greater risks to funding providers of adverse 
selection and moral hazard problems which increase the marginal cost of finance (Carpenter and Peterson 2002). Banks perceive early stage TBSFs to be too risky and do not fully understand the potential commercial value of innovation, particularly where information is limited and not always transparent (Schmid 2001) and assets are intangible and knowledge based (Hsu 2004). Also, the owners of innovative TBSFs may be reluctant to provide full information about their planned developments because of concerns that disclosure may make it easier for others to exploit their ideas (Shane and Cable 2002). Moreover, the use of standard credit scoring techniques by banks tends to favour established trading businesses with collateral rather than higher risk enterprises with intangible assets (Stiglitz and Weiss 1981; Bank of England 1996 and 2001; Cressy 2002). For their part, venture capital (VC) investors may consider the transaction costs of investing small amounts in seed and early stage ventures to be prohibitively expensive and risky (Trester 1998; Bruno and Tyebjee 1985; Lockett, Murray and Wright 2002) as they require a disproportionate amount of managerial input from VC fund managers relative to the size of the investment (Murray and Lingelbach 2009). Thus information asymmetry in the VC market arises not necessarily because the information is unavailable, but because it is too expensive to collect relative to the potential benefit from the investment. For these reasons therefore, younger TBSFs are likely to be more financially constrained than more established ones because of their lack of a trading history and greater information opaqueness. More specifically, those firms seeking early stage finance are expected to have experienced the greatest difficulties in obtaining both debt and equity finance over the 2007-2010 period. This is likely to have impacted most severely on more R\&D intensive businesses that are still at the pre-trading stage.

\section{Funding gaps in the finance escalator}

As a contemporary variant of the financial growth cycle model, the concept of a finance escalator is often used to identify the substitutability and transition from one type of funding to another that is needed to ensure the smooth, sequential development of innovative R\&D intensive small firms (NESTA 2009a; Mason, Jones, and Wells 2010). The finance escalator describes that, beyond the use of initial investment from the founders, family and friends, TBSFs rely on a staged sequence of types of external funding during their early development, with public and private sources often complementing each other (Oakey 2003). This typically involves access to four main types: (i) public 
seed grants; (ii) private equity from business angels and public supported venture capital; (iii) corporate and institutional venture capital; and (iv) bank debt finance. The types and combinations of external finance used will typically depend upon the stage reached in the product/service development cycle. First, during the pre-trading, initial feasibility stages, when the business concept is too risky for either debt or equity finance, public grant seed funding (i.e. for proof of concept) is often sought; second, during the early stages of R\&D prior to trading, private equity finance is accessed from business angels either acting individually or in syndicates; and third, during the later stages of development involving prototyping, manufacture and commercialisation (including sales and marketing and establishing foreign sales agents), larger scale private and corporate venture capital may be used. Additionally, if the TBSF is established with revenue income, or is close to commercialisation with proven markets, bank debt finance and other options (e.g. invoice financing) become available.

However, even before the recent financial crisis, there was mounting evidence that the escalator, at least as it applies in the UK, was not functioning as well as theory would suggest, resulting in a number of funding gaps concerning the availability of risk capital. For example, in relation to pretrading seed funding, Mason, Jones, and Wells (2010) suggest that it has proved historically difficult to generate commercial returns, due to high rates of failure, the intensive levels of investor management required and long periods to payback investments, with the result that the funding of this stage has become reliant on informal finance and public seed grants. In addition, there is evidence of a widening gap between early stage business angel equity finance and later stage private VC funding as institutional VCs in particular shift towards making fewer, less risky, later stage investments (Pierrakis and Mason 2008). For example, research in Scotland indicated that VCs have been shifting towards 'follow-on' and later stage rather than new investments, creating a larger gap for new and early stage risk capital and thereby constraining the availability of funding for the next generation of TBSFs (Johnston, Greig, and Harrison 2008; Harrison et al. 2010). This 'locking in' of equity funds to protect existing investments has exacerbated the situation, due in part to a lack of intermediate stage sales (i.e. between angels and VCs) and also final exits (e.g. IPOs, trade sales, licensing).

There are therefore a number of reasons for thinking that the finance escalator is not working as theory and government policy suggest it should. Mason, Jones and Wells (2010) for example 
describe recent UK financing of TBSFs as a protracted and drawn out 'drip feed' of investment, far from the slick and efficient finance escalator envisaged in the UK Government's Innovation Nation White Paper (BIS 2008). We are therefore interested to see whether our research evidence, combining experiences from the demand side with insights from the supply side, helps to identify various breakage points in the escalator as it relates to the financing of TBSFs since the onset of the financial crisis.

Given this literature context, this paper examines the following four propositions concerning the financing of TBSFs since the onset of the financial crisis:

(1) Younger TBSFs, especially those firms seeking early stage finance, are likely to have experienced the greatest difficulties in obtaining both debt and equity finance.

(2) More R\&D intensive businesses, such as those found in the bio/life sciences sector, are likely to have been the most financially constrained because of their greater reliance on attracting longer-term, equity capital.

(3) The growth of TBSFs is being stunted by a lack of external finance, especially those with the most growth potential.

(4) TBSFs are not experiencing the kind of smooth, sequential transition from one funding source to another envisaged by the finance escalator model, with their development being held back by a succession of funding gaps/breakage points.

The remainder of the paper sets out the methodology and then examines the key findings from the demand-side TBSF survey, focusing on the extent of their demand and access to different types of formal external finance and how this has impacted on growth and development. These findings are then discussed in relation to the key themes emerging from the supply-side interviews with finance providers, followed by the key conclusions and implications of the research findings.

\section{Research Methodology}

TBSFs can be subject to various definitional ambiguities because of their heterogeneity, operating across different sectors and at different stages of the production/service development cycle. According to government data sources (ABI 2008), they represent six per cent of the UK business population, are predominately micro businesses (over 90 per cent have less than 10 employees), and are dominated 
by IT businesses ( 80 per cent), with bio and life sciences and specialist R\&D businesses representing less than five per cent (Table 1). This research is not intended to be representative of the whole TBSF sector but focuses on small (less than 100 employees) independent technology based businesses operating in the growing sectors that have been associated with seeking risk finance in recent years (CEEDR 2010 and 2012; NESTA 2009b). The aim was to survey sufficient numbers of digital electronics/IT and bio/life science TBSFs to provide reliable insights into their experiences of trying to access finance. To achieve this the survey was weighted towards bio/life science businesses, with an emphasis on R\&D intensive activities (see Table 1 notes) rather than the IT consultancy services which swamp the TBSF sector numerically.

The focus is on surviving independent TBSFs and does not include trade sales or closures that occurred over the study period (2). An inevitable limitation of this survivorship bias in the sample is that the researchers do not know how many TBSFs went out of business (or never got off the ground) during the 2007-10 period because of the difficulties of obtaining finance.

The survey involved extended telephone interviews (typically half an hour in length) with ownermanagers and finance directors from two TBSF samples during the second half of 2010. The first sample comprised established TBSFs, located in four English regions (Greater London, East of England, South East, and North West) and Scotland. Initially the plan was to re-survey 50 out of 133 TBSFs previously surveyed on business financing in 2003 (Ullah and Taylor 2007). However, the low response rate (22 per cent), due mainly to TBSFs being untraceable ( 29 per cent), sold or acquired (11 per cent), or unable or unwilling to participate (38 per cent), necessitated the survey to be boosted by contacting previous non-respondent firms, resulting in a total of 51 completed interviews with established TBSFs. The second sample comprised younger TBSFs, established since 2005, random quota sampled from Dun \& Bradstreet's Global Reference Solutions UK database (3,333 TBSFs distributed evenly across the above English regions and Scotland). A total of 245 firms were contacted, resulting in 49 completed telephone interviews (20 per cent response) with younger TBSFs. It is acknowledged that some response bias may exist as it is problematic assessing non respondents' characteristics given the paucity of available data on these firms, particularly in respect of new TBSFs.

The sector distribution was closely matched between the established and younger TBSFs (Table 1), with the main sectors represented being electronic and scientific engineering (35 per cent), contract 
R\&D (22 per cent), IT (21 per cent) and pharmaceutical and chemical engineering (14 per cent). To facilitate broad sector comparisons, TBSFs were assigned as either bio/life science activities (38 firms) or electronics/IT activities (62 firms).

[Insert table 1 about here]

Uniquely amongst recent studies of TBSF financing, the research also involved obtaining a supply-side perspective by conducting 20 interviews (mostly by telephone although some face-to-face) with a range of debt, equity and grant financiers and intermediaries in early 2011 (Table 2). These interviews helped to enrich the interpretation of the findings from the demand side survey, enabling a more rounded view of the financial circumstances facing TBSFs. The finance providers and facilitators were drawn from Scotland and the English regions covered by the TBSF survey and were mostly selected using the researchers' existing contact networks.

[Insert table 2 about here]

Our empirical evidence therefore comprises both quantitative data from the survey of TBSFs and more qualitative data from the interviews with both TBSF entrepreneurs and finance providers. As well as undertaking univariate statistical analysis, binary logistic analysis was conducted on the survey data to explore the interrelationships between various characteristics of the TBSFs and identify the most significant factors. Specifically, the analysis focused on (i) whether or not firms had sought external finance; (ii) whether or not they had received finance, in both cases also running separate analyses of bank finance and equity finance; and (iii) whether or not firms experienced problems accessing external finance.

Before focusing on the ability of the TBSFs to access different sources of external finance during the period of the financial crisis, the next section of the paper profiles the characteristics of the surveyed businesses, including their growth orientation and performance over the 2007-10 period. 


\section{Characteristics and Growth Performance of Surveyed TBSFs}

The surveyed TBSFs are markedly different from the UK SME population as a whole, being more growth oriented and demonstrating a greater propensity to seek external formal finance, particularly equity finance. Analysis based on the UK Small Business Survey for both 2007 (Williams and Cowling 2009) and 2010 (IFF 2011), thereby covering the financing period of this research, acts as a benchmark for such comparisons.

Most of the established TBSFs had existed for at least ten years (median year of establishment, 1997). It is notable that almost one in ten of them had taken over three years to start trading, with bio/life science firms being more likely to require a longer lead time than their electronics/IT counterparts (19 per cent compared to 11 per cent took over one year). Just over a third (37 per cent) of all the surveyed TBSFs originated as spin outs from other companies or universities. This was significantly (.01 level) higher amongst the younger firms (53 per cent of them) than the established ones (22 per cent), possibly indicating that spin out companies, which tend to be the most innovative firms, were more likely to have been sold to or acquired by other companies at the commercialisation stage than their non-spin out counterparts (Wiklund and Söderblom 2006). A higher proportion of bio/life science (45 per cent of them) than electronics/IT (32 per cent) firms were spin outs.

The surveyed TBSFs were more growth oriented than SMEs as a whole, with 67 per cent of them aiming to grow during the period of the financial crisis (Table 3) compared to 53 per cent of SMEs having growth aspirations in 2007. Spin outs were the most growth orientated (76 per cent of them), whilst a fifth (21 per cent) of bio/life science firms were not ready to grow, this being indicative of the longer lead time to commercialisation for some young bio/life science firms.

[Insert table 3 about here]

Despite the economic recession, three fifths (59 per cent, $n=78$, proportionally the same when deflated turnover figures are used (3)) of the surveyed TBSFs managed to grow their sales turnover over the 2007-10 period, with less than a third (28 per cent) experiencing a decrease. This compares 
favourably with SMEs as a whole (35 per cent exhibiting sales growth in 2007 and 23 per cent in 2010). Just one third of TBSFs (Table 3) reported that growth had been constrained by weakening and in some cases falling demand, with the electronics/IT firms appearing to be more affected (43 per cent of them) than their bio/life science counterparts (24 per cent). The mean sales turnover of the established TBSFs increased by 35 per cent over the three years and that of their younger counterparts by 99 per cent (Table 4). The bio/life science TBSFs were faster growing than their electronics/IT counterparts, their mean sales turnover doubling compared to just a six per cent increase for electronics/IT firms.

The surveyed TBSFs also proved to be an important source of new jobs, with half (49 per cent) of those established by 2007 increasing their employment over the next three years, a considerably higher proportion than found amongst SMEs as a whole (5 per cent of which increased employment in 2007 and 11 per cent in 2010). The mean average employment growth for the surveyed TBSFs from 2007-10 was 3.2 employees, representing 32 per cent growth (Table 4). The established TBSFs increased their mean average employment by 26 per cent, whilst the younger TBSFs increased by 56 per cent. In line with their superior sales turnover performance, the mean employment increase for the bio/life science firms was six employees compared to 1.5 for the electronics/IT firms.

[Insert table 4 about here]

An overview is now presented of the demand for and success in obtaining different types of finance by the surveyed TBSFs over the 2007-10 period, based on analysing the business survey data, before using the more qualitative interview data to discuss the perspectives of both TBSF owner-managers and finance providers on recent changes in the availability of debt and risk capital.

\section{Access to Finance by Surveyed TBSFs}

As a result of their growth orientation and achievements, the surveyed TBSFs continued to have a relatively strong demand for finance over the 2007-10 period, particularly to fund working capital and R\&D. As shown in Table 5, the majority ( 81 per cent) were financed wholly or partly from internal sources, using personal funding and ploughing back profits. Two-fifths of these were solely dependent on internal sources and were significantly (.05 level) more likely to be small electronics (IT software and telecoms) consultancies with low overheads and no desire to use external finance. A higher 
proportion of younger TBSFs (10 per cent compared to two per cent of established TBSFs) used informal external finance from family and friends, confirming previous research indicating that TBSFs rely on personal and informal family finance in their early stages because they lack the collateral and track record required by banks and are likely to be considered to be too risky by equity investors (Mason and Harrison 2004).

[Insert table 5 about here]

The surveyed TBSFs were far more active in seeking external finance over the 2007-10 period than SMEs as a whole. Overall, two thirds (66 per cent) of the TBSFs had sought formal external finance, with just over half (53 per cent) being at least partially successful, often in combination with internal sources. This compares with 17 per cent of SMEs in 2007 and 18 per cent in 2010 seeking external finance in the previous year. The partial success rate of the surveyed TBSFs applying for finance (79 per cent) is in line with that for SMEs as a whole in 2007 (77 per cent) but considerably higher than in 2010 (57 per cent). It is notable that the majority ( 41 of 66 ) of TBSFs seeking formal external finance over the period tended to be active in doing so, seeking two or more types of formal external finance, which may in part relate to the difficulties in obtaining the full amount that they were seeking from a single source if not to the complementarity between different sources. These TBSFs were certainly more active in seeking multiple sources of finance than their SME counterparts where slightly under one third of finance seekers sought multiple sources. There was little difference between younger and established TBSFs in their use of formal sources (55 per cent and 52 per cent respectively), which was highest amongst bio/life science firms (66 per cent) and spin outs (61 per cent).

Binary logistic analysis, firstly using a series of tests to assess the significance of TBSF characteristics for all external finance seekers and those with trading performance records for 2007-10 (Table 6a: model 1), highlights the importance of external finance to bio/life science firms, as they were significantly (<.05 level) more likely to seek finance from formal sources and also significantly $(<.001$ level) more likely to receive it over the $2007-10$ period, as demonstrated by a second series of tests examining successful recipients amongst the applicant sub group (Table 6b: model 2a). When the stage of finance is included in the applicant sub group analysis (Table 6c: model 2b), it reveals that TBSFs seeking early stage funding were less likely to receive it than those requiring later stage 
funding (<.1 level), thereby confirming our first proposition that one of the severest effects of the financial crisis for TBSFs has been on the availability of early stage finance needed to develop and test new product ideas.

[Insert Tables $6 a, 6 b \& 6 c$ about here]

\section{Bank debt finance}

Bank debt finance was the most commonly sourced finance. Half the surveyed TBSFs approached banks from 2007-10, with a higher proportion of younger (60 per cent) TBSFs doing so than established (40 per cent) firms. This might not be what we would expect from the finance escalator model, but it should be noted that the younger businesses seeking bank finance included a significantly (.01 level) high proportion of 'soft starts' where founding entrepreneurs relied on revenue generated from R\&D consultancy to finance their own product development and commercialisation (Bullock, 1983). Binary logistic analysis indicates that bio/life science firms were more likely to seek (although only at .25 level) and receive (<.05 level) bank finance than electronics/IT firms, indicating the importance of this source of finance to these TBSFs. This analysis also indicates that firms seeking early stage finance from banks were less likely to receive it than those seeking later stage finance (<.01 level; Table 6c).

Over a third of TBSFs (36 per cent) applied for overdrafts and one quarter applied for term loans (Table 7). The majority applying for overdraft facilities were successful to some extent ( 81 per cent) as were those applying for term loans, although to a lesser extent (58 per cent). However bank loans proved more difficult to obtain on terms that were acceptable to TBSF owner-managers. More than a third (10 cases) of the 25 loan applications were turned down by the banks, mainly relating to insufficient trading record and collateral for younger TBSFs and changes resulting in more restrictive bank lending policy impacting on established TBSFs. However, even when bank loans were offered, they were not always taken up. Only nine of the 13 firms that were offered term loans eventually took them up because some owner-managers found the conditions relating to the level of personal guarantee and collateral and costs (fees and interest rates) unacceptable.

[Insert Table 7 about here] 


\section{VC and equity finance}

Although many TBSF owner-managers remained reluctant to seek equity finance, largely because of concerns about the implications for retaining managerial control of their business, it is clear that access to equity and venture capital is important for a significant proportion of them, especially those needing risk capital to finance $R \& D$, product testing and commercialisation. Whereas 23 per cent of surveyed TBSFs sought VC and equity finance during the 2007-10 period, this compares with less than one per cent of the SME population as a whole in both 2007 and 2010. More than a third (37 per cent) of the bio/life science and 29 per cent of spin out TBSFs sought this type of finance. This is confirmed by the binary logistic analysis which shows that the bio/life science TBSFs were significantly more likely to seek (.01 level) and obtain (.01 level) VC and equity finance (Tables $6 a$ and 6b), underlining the greater reliance of these businesses on this type of funding. One in eight TBSFs (12 per cent) applied to VC funds and one in seven (14 per cent) approached business angels (Table 7). In line with the escalator, younger firms were more likely to seek funding from business angels and public backed VC funds (such as the Scottish Co-Investment Fund) and older firms from corporate and institutional VC funds.

Only half (11 firms/13 applications) of the TBSFs approaching equity/VC financiers received offers, typically for $R \& D$ in early stage product development and later stage product proofing/technical standards and working capital for manufacture, sales, marketing and distribution. Successful VC applications by established TBSFs were mainly for top-up or follow-on later stage VC finance from existing investors. However, not all the offers of risk capital were taken up, resulting in less than half of the cases successfully reaching a deal (Table 7). This was notably the case with business angel finance, with offers being rejected because business owner-managers were not prepared to relinquish the level of equity that investors required to compensate for low valuations at these early stages. The multivariate analysis shows that those TBSFs seeking their first round of equity finance during the 2007-10 period had the greatest difficulties in obtaining it (<.05 level; Table 6c), underlining the problems new and early stage TBSFs that are R\&D intensive typically face in attracting external investors to their business. 


\section{Other types of finance}

One quarter of the surveyed TBSFs applied for public sector grants and awards over the 2007-10 period and 16 per cent applied for a variety of other finance sources including bank asset finance, supplier finance, and joint venture finance. The vast majority (88 per cent) of grant applications were completely successful, with a further eight per cent receiving at least some of the grant funding applied for (Table 7). Grants ranged from small-scale marketing and export grants to sizeable R\&D grants (including SMART awards in the case of Scottish TBSFs) and European FP7 awards involving collaboration between TBSFs and universities. Younger TBSFs (30 per cent of them) were particularly active and successful in seeking grants, notably in relation to innovation and product $R \& D$, underlining the important role of early stage public backed seed funding (Oakey 2003; Murray 2007). With one or two exceptions, the TBSFs were able to find the matched funding required.

The use of other forms of external finance was largely driven by failure to secure all or at least some of the formal funding applied for from banks and equity investors. For example, businesses that were unable to obtain or increase overdraft facilities for working capital and to alleviate short-term cash-flow issues were highly likely to use personal credit card finance, with at least two businesses raising in excess of $£ 10,000$ in order to service new customer orders. A concern for longer term R\&D projects, notably in bio/life sciences, was the problem of being beyond the initial concept grant stage, but not advanced enough to attract investment from large pharmaceutical companies, larger VC funding or term loan bank finance. This led to several businesses existing on a part-time or free labour basis, with minimal investment from universities or private individuals such as family and friends. In a couple of exceptional cases, nearer to the prototyping stage, the businesses had managed to secure funding from customer investors who could gain a market leading advantage from a new innovative product.

\section{External finance and growth performance}

The above findings therefore present a rather mixed picture in terms of the ability of the surveyed TBSFs to obtain formal external finance over the 2007-10 period, with a high level of success being achieved in relation to bank overdraft finance and grant based finance on the one hand, but greater difficulty being experienced in obtaining bank loan finance and equity finance on the other. Overall, more than four fifths (82 per cent) of TBSFs seeking formal external finance in this period stated that it 
had become harder to obtain. More than one third (36 per cent) reported problems in accessing formal external finance that negatively impacted on their business performance, whereas nine per cent of the SME population as a whole were similarly affected in this period (IFF 2011). Most affected were younger TBSFs (41 per cent of them), spin outs (52 per cent) and bioscience firms (45 per cent), typically experiencing slower growth as R\&D, product development, manufacturing and sales developments were curtailed. More than a quarter (26 per cent) had slowed down or reduced R\&D activity and a number of longer term R\&D projects had gone into virtual hibernation for periods of many months whilst time and existing funding was spent searching for further finance. Binary logistic analysis (Table 6d) demonstrates that spin outs were most significantly affected $(<.05$ level) by a lack of external finance, as well as being significantly (<.05 level) correlated with those firms reporting being affected by the credit crunch. Problems in obtaining external finance had a negative impact on the sales performance from 2007 to 2010 of trading businesses, as a significantly higher proportion (<.1 level) of those reporting such problems failed to achieve sales turnover growth. Those trading businesses experiencing problems accessing bank finance (particularly loan finance) were most significantly affected (<.01 level).

\section{[Insert Table 6d about here]}

Unsurprisingly, it was the fastest growing TBSFs that had the greatest demand for external finance. Two fifths of surveyed TBSFs trading between 2007-10 exhibited high growth (defined as at least 50 per cent increase in sales turnover in this period) and of these, 71 per cent sought formal external finance compared to 57 per cent of their lower growth counterparts (4). Whilst the binary logistic analysis does not reveal any significant evidence that these high growth TBSFs had been adversely affected by lack of external finance, these businesses were significantly $(<.01$ level) more likely to seek equity finance than their lower growth counterparts and demonstrated a slightly higher tendency to report negative impacts due to receiving less finance than required (39 per cent compared to 30 per cent). Overall, the evidence here suggests that the surveyed TBSFs are more growth oriented than typical UK SMEs, are more likely to seek external finance, particularly equity finance, but that their growth is being held back by difficulties in accessing the finance need (supporting our third proposition). Moreover, this is significantly worse for the growth oriented spinout TBSFs. 


\section{Perspectives of Business Owner-Managers and Finance Providers}

\section{Bank debt finance}

There was agreement amongst both business owner-managers and finance providers that accessing bank finance had become more difficult as a result of the actions taken by the banks in responding to the financial crisis. There were a number of interrelated aspects to this.

First, it was noted that the banks had become more cautious and risk averse in lending to TBSFs. In reviewing applications for debt finance, banks are primarily concerned with assessing downside risks i.e. the ability of the business to repay the loan as well as the security that the business can offer against the possibility of defaulting on the loan. Our evidence is consistent with Berger and Udell's (1998) prediction that financial distress in the banking sector will have an adverse impact on small firms as banks cut back on lending to reduce their credit risk exposure and rebuild their capital bases. As a result of the market uncertainties during the recent economic downturn, banks have been pushing more of the risks onto businesses themselves, by requiring more asset based security and directors' guarantees than previously as well as wanting to see more proof of advance orders and sales contracts before advancing finance. The latter proved particularly difficult for some younger TBSFs that needed more funding to be able to market and manufacture their products, but could not secure bank financing until they could show that they had definite orders. The CEO of a young digital measuring device company explained these difficulties: "We required $£ 170,000$ to fund a product launch and I was amazed when my bank was unwilling to support a loan backed by my £1 million home. It took a while but I eventually obtained a personal mortgage loan from the third bank visited."

An indication of the risks that bankers perceive in lending to TBSFs is the surprisingly high proportion of loan applications (12 of the 25 businesses applying for bank loans) which were made under either the Small Firms Loan Guarantee (SFLG) or the subsequent Enterprise Finance Guarantee (EFG) schemes (5), given that SFLG/EFG is designed to operate at the margins of commercial lending decisions, affecting between one and two per cent of all bank loans. This could indicate that the surveyed TBSFs were either more knowledgeable about the bank lending market than most SMEs, or were seen as being more marginal in bank lending terms. Since most of the TBSFs that applied under 
the SFLG/EFG schemes were unsuccessful, it would seem to indicate that the banks still viewed them as unattractive lending propositions despite the government guarantee. Others were offered loans but found the terms unacceptable, as in the case of an owner-manager who found that: "even under the EFG, I was still required to put up a 25 per cent personal guarantee".

Second, obtaining debt finance had become more expensive for many TBSFs as a result of changes in bank policy, with the tightening up of bank finance through the Basel regulations (6) leading to banks reducing their debt exposure and passing their increased costs onto customers. Many TBSF owner managers complained about the higher interest rates as well as increased set up and arrangement fees. For example, one owner-manager complained: "The bank's offer was quite steep. We were required to pay a 9.7 per cent fixed rate, 2 per cent ongoing underwriting charges and with a 1.5 per cent set-up fee for a $£ 100,000$ loan". Another owner-manager mentioned: "The bank offered us 7 per cent above base, with a half per cent set-up fee and a requirement that the entire $£ 800,000$ loan be secured by the directors' personal assets, which we found unacceptable."

Others found that banks were only prepared to offer more expensive forms of finance (e.g. invoice financing based on sales order books). As mentioned above, four out of the thirteen businesses that were offered bank loans decided not to take them up because they found the terms and conditions unacceptable. One owner manager summed up why they rejected the bank's offer as follows: "We had been in a similar position a few years ago, both parties knew that nothing had changed but, unlike previously, the bank was prepared to offer but on totally unacceptable terms both with regard to interest rates and personal guarantees. There was clearly no point in pursuing matters further." This comment indicates that some TBSF managers' expectations of the costs of obtaining debt finance were based on their previous experience at a time when debt finance was relatively cheap and the risks of default less than in the current economic circumstances. These unacceptable terms and conditions are likely to discourage TBSFs from seeking bank finance in the future, resulting in a growing latent demand for debt finance (Fraser 2009; Oakey 2007).

Third, from the perspective of the interviewed bankers themselves, debt finance was not what many of the businesses needed, particularly in the case of new and young TBSFs. They commented that inexperienced TBSF owner managers often did not understand the difference between debt and equity finance and that they turned down some applications because businesses needed more equity to fund 
the early stages of business development. This indicates a knowledge gap on the part of those ownermanagers who are more familiar with internal and debt financing and less familiar with the sources of capital needed to fund growth (Van Auken 2001). This is supported by the business survey evidence as younger TBSFs appeared to be less knowledgeable about equity funding than their more established counterparts, most of whom had managers with previous experience of accessing this type of finance.

Based on the interconnections in the finance escalator between different sources of finance, it might be expected that success in attracting investment from business angels or VC funds would improve a business's chances of obtaining bank debt finance, one of the benefits of angel and VC involvement being that it can reduce information asymmetries thereby facilitating access to other forms of capital (Colombo and Grilli 2010). However, there were very few examples from our TBSF survey of this occurring during the financial crisis, one exception being a young biotechnology company that managed to obtain a £250,000 SFLGS loan on the back of successfully negotiating £3 million of equity funding from a public supported VC fund and a business angel network.

And fourth, from the perspective of most business owner-managers themselves, the relationship they have with their existing bank is important to them, despite the difficulties they may have experienced in accessing finance. Whilst longer relationships are considered to improve the availability of finance and lending terms (e.g. lower collateral requirements and bank charges) (Berger and Udell 1995), recent research showed an increase in bank switching during the financial crisis as a result of dissatisfaction with bank charges and terms (Fraser, 2009). However, two thirds (64 per cent) of the surveyed TBSFs seeking bank finance were reluctant to shop around, preferring to stay with the bank with which they had an existing relationship (for new firms, often through personal banking experience) and assuming that if they were unsuccessful, they would be unlikely to fare any better with other banks.

A common criticism amongst surveyed TBSF owner-managers was that their local relationship manager appeared to have little influence when it came to making the final decision on their funding applications which, apart from those relating to small overdraft facilities, tended to be made centrally. Typical comments included: "we experienced a high turnover of local managers, making it difficult to develop a relationship" and that "local managers are more interested in selling the bank's products rather than trying to understand the needs of the business". A common view was that there had been 
a deskilling of business knowledge and understanding at the local branch level over recent years. Moreover, relationship banking has taken a back seat since the onset of the credit crunch as banks have placed more emphasis on the results of using computerised capital based risk assessment methods. As Freel (2007) found in research on small firms applying for bank loans, this trend has particularly worked against the interests of small innovative and R\&D intensive firms given their limited tangible assets and greater market uncertainties.

Also, there are grounds for thinking that the bank mergers that have been a response to the credit crunch have resulted in the banks themselves investing less in relationship banking, given previous arguments that there is less incentive for banks to pursue relationship banking when there is less competition between them because of less pressure to differentiate their services (Boot and Thakor 2000). This would suggest that the increasing consolidation of banking is resulting in individual banks becoming less customer driven and client focused than previously.

\section{$V C$ \& equity finance}

As mentioned earlier, there has been a reduction in new private and institutional equity finance in the UK over the last decade, leaving an equity gap particularly for new and early stage TBSFs. Our study evidence tends to confirm the existence of this equity gap and suggests that, if anything the financial crisis has resulted in a further widening of the gap due to several related factors.

First, unlike the banks where the focus is largely on downside risks, VC investors are primarily concerned with assessing the upside potential of the business and the probability of making a return on their investments. According to the interviewed investors, their main criteria in assessing applications are the presence of a strong management team, preferably with a proven track record and/or willingness to strengthen management capabilities by taking on non executive directors with commercial and sector specific skills; a novel and 'big enough idea' to be interesting; a clear route to market and potential for fulfilling a market need; and an exit strategy whereby the investment is saleable to others. However, the market uncertainties associated with the economic downturn have meant that it has become more difficult to satisfy these criteria, leading to greater uncertainties about the likelihood of business success. 
Second, potential investors have become deterred from making new investments in new and early stage TBSFs by the poor returns on their existing investments and the difficulties of exiting from them. It is now taking longer than normal to realise returns on investments, with increased funding rounds being necessary to ensure the survival of the business and meet the rising cost of R\&D. In addition, more incremental stages of business angel follow-on investment have become necessary to bridge the gap created by the shift of VC funds to lower risk later stage investments. Thus funds have become locked into existing investments rather than becoming available for new investments.

The difficulties of obtaining early stage equity finance were also apparent from the TBSF survey. Five of the eight businesses that made unsuccessful applications for equity funding were rejected because the finance was for early stage product developments that investors considered to be too risky and not ready for investment. For example, a director of a university spin out business concerned with biomass power technology who had previous equity raising experience observed that it was getting harder to find early stage equity finance, having spent two years searching without yet finalising a deal: "the main barrier is getting the initial tranche of equity finance and this has held back the development of the business". And the CEO of another university spin out biotechnology business observed that: "it is getting harder to raise funds as there seem to be fewer investors and those that are investing are sticking to their current investments", whilst the finance director of a bio-tech company questioned "the short-sightedness of lurching through numerous tranches of small scale equity funding in the hope of achieving eventual success." Several of these businesses had found themselves struggling for funding, after initial seed grant and founder investment, with R\&D work progressing slower than planned whilst the search for equity investment ensued. One bio science business had been "seeking funding for over three years", whilst a chemical soil testing business had "explored many forms of venture capital including government backed schemes, but they don't understand our business and want to see orders, done deals and guaranteed success."

Third, despite these difficulties on the supply side, the view of interviewed investors and fund managers was that the demand for equity finance had grown over the last three years, this being seen as a shift away from bank debt finance which had become more expensive. Other recent research has also suggested that the difficulties in obtaining debt finance may lead more small firms to seek external equity funding if they are not prepared to abandon their investment projects 
altogether (Cowling, Liu and Ledger 2012). It is interesting to note in this respect that the TBSF survey evidence showed that a higher proportion (19 per cent) of TBSFs were expecting to be seeking equity finance over the next three years than expected to apply for bank finance (14 per cent). Equity investors indicated that they may look at hundreds of investment proposals annually, but actually invest in very few, typically less than five and sometimes just one or two new investments. They also indicated that they have become more cautious and protective of their investments, requiring more stringent due diligence, tighter legal requirements and increased equity shareholdings, which has led to a doubling in the time to find, negotiate and arrange finance. Moreover, several investors felt that the lack of success reflected the insufficient quality of applications received and that more professionalism and innovativeness is needed in the applications from TBSF entrepreneurs. From a supply side perspective therefore, there is a demand side problem relating to a lack of attractive investment propositions as well as a need for business investor readiness programmes (Mason and Harrison 2001; Mason and Kwok 2010; Rasmussen and Sørheim 2012).

Fourth, it would appear that investors are, if anything requiring larger stakes in investee businesses than in the past. Our survey evidence shows that the 13 TBSFs that were successful in obtaining equity/VC finance were willing to cede considerable equity share in their businesses (median 25 per cent). Unsurprisingly, there tended to be a greater willingness to cede equity in the case of spin out companies than non spin outs. In the most extreme case of an R\&D intensive spin out needing a substantial investment ( $£ 10$ million) to progress products to clinical trials and licensing sales, the owners found that: "even though we were willing to offer up to 90 per cent of the business, there was no interest in early stage funding from private VC or corporate funds". However, several TBSFs rejected the offers they received because they were not prepared to relinquish the share of equity asked for. For example, a new TBSF rejected $£ 100,000$ of business angel funding after a search of 18 months because: "although this funding would have been ideal for product development, the investor wanted more than the 25 per cent share offered."

And finally, fund managers and industry experts also highlighted two other issues which are disturbing the flow of equity investment in the UK. First, even with the development of angel syndicates/ networks, they are not always able to see investment projects through to achieving a satisfactory return by making successive follow-on investments. This situation has been exacerbated by private 
VC funds withdrawing investments to later stages and instances of 'crushing', whereby angels are not able to sell their investments to VCs at optimal market rates, because the VC funds hold back until they can negotiate more advantageous terms for their investments (Lerner et al. 2011). And second, the combination of a slow down in intermediate (i.e. angel sales to VCs) and final trade sale activity in the UK has led to protraction of the development cycle and locking-in of investment funds. For example, Mason et al (2010) presents London Stock Exchange data for small-scale IPOs in the UK AIM market demonstrating a fall from peak fund raising in 2006 of over $£ 6.5$ billion in over 300 companies to less than $£ 1$ billion in fewer than 20 companies for 2008 and 2009. Accordingly, the UK now lacks a culture of multi-stage investment and a healthy public market exit route (Lerner et al. 2011).

\section{Grant based finance}

Over the last decade there has been a growing role for public backed finance initiatives, with the UK government becoming a major source of seed and early stage finance (Oakey 2003; Murray 2007; Wright et al. 2006). Early stage investments with public backing increased from 20 per cent in 2000 to 68 per cent by 2008 (Pierrakis 2010). The majority of interviewed finance providers agreed that government has a vital role in filling the gap left by the banks and the VCs in seed and early stage funding, such as through grant schemes and public backed VC and mezzanine funds (e.g. Enterprise Capital Funds). Interestingly, some interviewees felt that as a means of achieving national economic recovery and growth, there was now a need for a greater volume of deals involving public backed finance in order to meet early stage finance demand, enabling more TBSFs to grow, spawn other enterprises and generate multiplier effects (7).

As detailed above, public sector grants have been an important source of finance for R\&D over the 2007-10 period for a quarter of the surveyed TBSFs. However, there were concerns that current UK public spending cutbacks together with the shift from a regionally targeted funding mechanism to a national competitive mechanism will reduce the amount of grant funding available to new and early stage TBSFs. Yet an important positive externality of public programmes aimed at innovative small firms is that they certify early stage projects (Lerner 1999). Thus R\&D grants can be perceived by other finance providers as helping to accredit technological innovations, thereby helping to reduce the 
risks associated with information asymmetry (Murray and Lott 1995). It follows that if the money devoted to R\&D grants is reduced and they become more difficult to obtain, this could in turn make it more difficult for TBSFs to secure other sources of finance.

\section{Conclusions}

The evidence presented in this paper from a survey of surviving independent UK TBSFs demonstrates that they were more growth seeking and active in seeking formal external finance over the 2007-10 period than SMEs as a whole, maintaining a strong demand for both debt and equity finance since the onset of the financial crisis in 2007 and continuing to forecast strong demand for finance over the next three years. This was particularly the case for TBSFs in the bio/life sciences, which tend to be R\&D intensive firms with a high demand for equity risk finance. Overall, these businesses appear to have been less affected by demand constraints during the economic downturn than their electronic/lT counterparts, and achieved stronger growth in sales turnover and employment. However, accessing formal external finance has become more difficult and is expected by TBSF owner-managers to remain so, with our findings showing those TBSFs seeking early stage finance to be the worst affected. More than a third of TBSFs considered that financial constraints had held back their growth, noticeably the case with spin outs and bio/life science firms which tend to be the most $R \& D$ intensive and innovative businesses. Two thirds of those expecting to need external finance in the next few years harboured concerns about their ability to access it.

The more interpretive evidence from both TBSF owner-managers and finance providers confirms our fourth proposition that the interconnectedness and substitutability between different sources of finance required for the continuity of funding has proved difficult to achieve under recent financial market conditions. More specifically, as applied to the UK, the finance escalator model has become 'deeply flawed' (Gill 2010), with a number of break points along the stages of the business and innovation development cycle which are slowing progress and potentially holding back growth. This study highlights four key breakages in the escalator, where further market intervention by government may be required. 
First, the study reveals a considerable demand and use of seed and early stage finance. Whilst soft starts have been shown to be able to access bank debt finance, because they already have customers and order books, for more intensive R\&D activities grant finance has proved vital. Recent reductions in UK seed grant funds and the shift from an established regionally targeted funding mechanism to a national competitive mechanism have raised concerns amongst younger surveyed TBSFs. This type of finance is not only crucial to getting R\&D underway, but has also proved a catalyst for leveraging in finance from other sources.

Second, the existing equity finance gap (commonly thought to be in the $£ 250,000$ to $£ 2 m$ range) has been exacerbated by business angel investment blockages and a shortfall of new early stage private equity investment, along with the continuing trend for VCs to make fewer, but larger sized investments focused at later stages. Consequently, there is a growing divide between angels and private VC funds, representing a considerable step in the finance escalator, with signs that new later stage VC funding has become much harder to secure. The overall picture is of less small-scale equity funding being available and a sourcing process which has doubled in length with considerably increased cost (both in administration and equity share).

Third, in relation to debt finance, our evidence indicates that TBSFs have been adversely affected by the actions taken by banks to reduce their debt exposure and to transfer more of the risks onto businesses themselves. For more established businesses where debt finance was offered, in several cases the terms were too expensive or demanding, requiring higher levels of security and collateral than the owner-managers were prepared to accept. In part, it may be argued that debt finance is available, but that the owner-managers perceptions are based on their experiences during the previous era of cheap finance.

Fourth, it is increasingly evident that longer-scale intensive R\&D found in bio/life sciences and clean/alternative energies requires equity risk financing at levels which go far beyond the present EU state aid cap of $£ 2$ million for public supported VC schemes, perhaps as high as $£ 10$ million (Rowlands 2009). This study found a number of ventures that, after initial seed funding, were laying almost dormant over several years whilst owner-managers took on an almost full-time job seeking 
middle stage R\&D equity risk finance. With the decline in the UK IPO market (Mason, Jones and Wells 2010) there is a growing demand for larger scale middle stage equity funding that is prepared to invest for at least 3-5 years, rather than the later stage funding which is perceived as offering lower risk and quicker returns over 1-3 years and that private/institutional VCs are currently investing in.

This paper therefore supports the view that there are a number of breakage points in the UK finance escalator which are resulting in a widening and deepening of the finance gap facing TBSFs, and holding back their growth. This is not just for early stage finance, but increasingly for later stage R\&D investment as well. A variety of forms of government intervention are required in order to stimulate private investment and achieve the interconnectedness between the different sources of finance needed for the smooth, sequential financing of TBSFs. These public initiatives should include the maintenance of an adequate level of grant seed funding; the stimulation of private sector investment (such as via the existing Enterprise Investment Scheme); continued interventions to provide smallscale earlier stage VC funding preferably through scaled-up public VC funds and co-investment initiatives with business angels; and larger scale, perhaps pan European public backed VC schemes (such as the current UK Innovation Investment Fund) which can plug the gap in larger mid-stage funding. In the current economic climate, these would appear to be essential cornerstones to assisting future TBSF growth and development.

\section{Acknowledgements}

The research on which this paper is based was supported by a grant from the Institute for Small Business and Entrepreneurship's Research and Knowledge Exchange (RAKE) Initiative in 2009-10. The authors are also grateful for the helpful comments of three anonymous referees. 


\section{End Notes:}

(1) TBSFs are defined broadly here as independently owned and managed enterprises with less than 250 employees whose products and services embody innovative and advanced technologies developed by the application of scientific and technological expertise and fit within the high tech sectors defined by Bullock and Millner (2003).

(2) It may be argued that trade sales are representative of the more successful TBSF outcomes, but they may also result from poor performing businesses being acquired cheaply. The management and characteristics of trade sales businesses remaining in the UK are also likely to be transformed into a mature large business context. These larger businesses will have completely different financing structures and relationships with financing organisations and will be difficult to reconcile within this study of independent TBSFs.

(3) 2010 sales turnover deflated by 105.9 (i.e. 94.4 per cent) to reflect UK GDP growth from base year of 2007 (source: UK Office of National Statistics).

(4) Interestingly, this is in line with the trend found in the Eurostat (2011) SME access to finance data covering the same period from 20 European Union countries. This showed that high growth (59 per cent) and gazelle SMEs (57 per cent) exhibited higher demand for finance than their lower growth counterparts (just over 50 per cent).

(5)The SFLG, first introduced in 1981, was the UK's publicly funded debt guarantee scheme until January 2009 when it was replaced by the EFG in an attempt to stimulate additional bank lending to SMEs.

(6) Basel III (16/12/2010) requires that: banks hold 4.5 per cent common equity (up from 2 per cent) and 6 per cent of Tier I capital (up from 4 per cent) of risk-weighted assets; introduce a mandatory capital conservation buffer of 2.5 per cent and discretionary countercyclical buffer of up to 2.5 per cent of capital during periods of high credit growth; introduce a minimum 3 per cent leverage ratio and two required liquidity ratios, requiring banks hold sufficient high-quality liquid assets to cover total net cash flows over 30 days; the Net Stable Funding Ratio requires the available amount of stable funding to exceed the required amount of stable funding over a one-year period of extended stress.

(7) It is interesting to note that support for this view comes from Lerner (2010) who argues that government backed VC programmes (in the US and Europe) have tended to be concentrated in periods when VC funds were at their most active anyway, whereas it is periods such as the recent financial crisis when public backed programmes are most needed. 


\section{References}

ABI. 2008. Annual Business Inquiry. Office for National Statistics, UK Government.

Bank of England. 1996. The Financing of Technology-based Small Firms. London: Bank of England.

Bank of England. 2001. The Financing of Technology-based Small Firms. London: Bank of England.

Berger, A.N.,and G.F. Udell.1995. Relationship banking and lines of credit in small firm finance. Journal of Business 68 no.3: 351-81.

Berger, A. N., and G.F. Udell. 1998. The economics of small business finance: the roles of private equity and debt markets in the financial growth cycle. Journal of Banking and Finance, 22: 613-673.

BIS. 2008. Innovation Nation. UK Government White Paper, Department for Business, Innovation and Skills. London: UK Government.

Boot, A., and A.Thakor. 2000. Can relationship banking survive competition? Journal of Finance 55 no.2: $679-713$.

Bougheas, S., P. Mizena, and C. Yalcinb. 2006. Access to external finance: Theory and evidence on the impact of monetary policy and firm-specific characteristics. Journal of Banking and Finance 30 no.1:199-227.

Bruno, A. V., and T.T.Tyebjee. 1985. The entrepreneur's search for capital. Journal of Business Venturing, 1: 61-74.

Bullock, A. and I. Millner. 2003. Innovation Benchmarking Methodology. Centre for Business Research Paper, University of Cambridge.

Bullock, M. 1983. Academic enterprise, industrial innovation and the development of high technology financing in the United States. London: Brand Brothers and Co.

Carpenter, R.E., and B.C. Peterson. 2002. Capital market imperfections, high-tech investment, and new equity financing. The Economic Journal 112 :F54-F72.

CEEDR 2010. Early assessment of the impact of BIS equity fund initiatives. CEEDR Report to the Department for Business Innovation and Skills. July 2010. Sheffield: BIS Enterprise Directorate.

CEEDR 2012. Early assessment of the UK Innovation Investment Fund. CEEDR Report to the Department for Business Innovation and Skills, May 2012. BIS Enterprise Directorate.

Colombo, M.G., and L. Grilli. 2010. On growth drivers of high-tech start-ups: exploring the role of founders' human capital and venture capital. Journal of Business Venturing 25: 610-626.

Cosh, A., A. Hughes, A.Bullock, and I. Milner. 2009. SME Finance and Innovation in the Current Economic Crisis. Centre for Business Research, University of Cambridge.

Cowling, M., W. Liu, and A. Ledger. 2012. Small business financing in the UK before and during the current financial crisis. International Small Business Journal 30 no. 7: 778-800.

Cressy, R. 2002. Funding Gaps: A Symposium. The Economic Journal 112: F1-F16.

Eurostat. 2011. Access to Finance Survey. Enterprise and Industry, European Commission.

Fraser, S. 2009. Small Firms in the Credit Crisis: Evidence from the UK survey of SME finances. Warwick Business School, University of Warwick.

Freel, M.S. 2007. Are small innovators credit rationed?, Small Business Economics, 28: 23-35. 
Gill, D. 2010. Collapse of the Funding Escalator. Presentation to the Institute for Management, St John's Innovation. 24 June 2010.

Harrison, R., G. Don, K.G. Johnston, and M. Greig. 2010. The early-stage risk capital market in Scotland since 2000: issues of scale, characteristics and market efficiency. Venture Capital 12 no. 3 : 211-239.

Hsu D. 2004. What do entrepreneurs pay for venture capital affiliation? The Journal of Finance LIX: 1805-1844.

IFF. 2010. Results from the 2009 Finance Survey of SMEs. Report by IFF Research for Department for Business Innovation and Skills. Sheffield: BIS Enterprise Directorate.

IFF 2011. BIS Small Business Survey. 2010. Report by IFF Research for the Department for Business Innovation and Skills. Sheffield: BIS Enterprise Directorate.

Johnston, K. G, M. Greig, and R.T. Harrison. 2008. The risk capital market in Scotland 2005-2007. Glasgow: Scottish Enterprise.

Lerner, J. 1999. The government as venture capitalist: the long-run impact of the SBR programme. Journal of Business 72 no. 3: 285-318.

Lerner, J. 2010. Innovation, Entrepreneurship and Financial Market Cycles, OECD Science, Technology and Industry Working Paper 2010/03. Paris: OECD.

Lerner, J., Y. Pierrakis, L. Collins, and A.B. Biosca. 2011. Atlantic drift: venture capital performance in the UK and the US. NESTA Research Report June 2011. London: NESTA.

Lockett, A., G.C. Murray, and M. Wright. 2002. Do venture capitalists still have a bias against technology based investments?, Research Policy 31: 1009-1030.

Mason, C.M., and R.T. Harrison. 2001. Investment readiness: A critique of government proposals to increase the demand for venture capital. Regional Studies 35 no.7: 663 - 668.

Mason, C.M., and R.T. Harrison. 2004. Does investing in high technology-based firms involve higher risk? An exploratory study of the performance of technology and non-technology investments by business angels. Venture Capital 6 no.4: 313-332.

Mason, C.M., and J. Kwok. 2010. Investment readiness programmes and access to finance: a critical review of design issues. Local Economy 25 no.4: 269-292.

Mason C.M., L. Jones, and S. Wells. 2010. The City's Role in Providing for the Public Equity Financing Needs of UK SMEs. Report to the City of London by URS Corporation. March 2010.

Murray, G.C. 2007. 'Venture capital and government policy. In Handbook of research on venture capital, ed. H. Landstrom, 113-51. Cheltenham: Edward Elgar.

Murray, G. C., and D. Lingelbach. 2009. Twelve Meditations on Venture Capital. University of Exeter Business School, Paper No. 09/06.

Murray, G.C., and J. Lott. 1995. Have venture capital firms a bias against investment in high technology companies? Research Policy 24: 283-299.

NESTA. 2009a. From funding gaps to thin markets: UK Government support for early-stage venture capital. Research Report September 2009. London: NESTA.

NESTA. 2009b. The vital 6 per cent: how high growth innovative businesses generate prosperity and jobs. Research Report October 2009. London: NESTA. 
Oakey, R.P. 2003. Funding innovation and growth in UK new technology-based firms: some observations on contributions from the public and private sectors. Venture Capital 5 no.2: 161-180.

Oakey, R. P. 2007. A commentary on gaps in funding for moderate 'non-stellar' growth small businesses in the United Kingdom. Venture Capital 9 no. 3: 223-235.

Pierrakis, Y. 2010. Venture capital: now and after the dotcom crash. NESTA Research Report July 2010. London: NESTA.

Pierrakis, Y., and C. Mason. 2008. Shifting sands: the changing nature of the early stage venture capital market in the UK. Research Report September 2008. London: NESTA.

Rasmussen, E., and R. Sørheim. 2012. Obtaining early-stage finance for technology entrepreneurship: the demand side perspective. Venture Capital 14 no. 2-3: 77-89.

Rowlands, C. 2009. The Provision of Growth Capital to Small and Medium Sized Enterprises. Report for the UK Government. Norwich: The Stationery Office.

Siegel, D.S., P. Westhead, and M. Wright. 2003. Science parks and the performance of new technology-based firms: a review of recent U.K. evidence and an agenda for future research. Small Business Economics 20: 177-184.

Schmid, F. 2001. Equity financing and the entrepreneurial firm. Federal Reserve Bank of St. Louis Review 83: 15-28.

Shane S., and D. Cable. 2002. Network ties, reputation and the financing of a new venture. Management Science 48: 364-382.

Stiglitz, J. E., and A. Weiss. 1981. Credit rationing in markets with imperfect information. The American Economic Review 71 no. 3: 393-410.

Trester, J. J. 1998. Venture capital contracting under asymmetric information. Journal of Banking and Finance 22: 675-699.

Ullah, F., and P. Taylor. 2007. Are UK technology-based small firms still finance constrained? The International Entrepreneurship and Management Journal 3 no.2: 189-203.

Van Auken, H. 2001. Financing small technology-based companies: the relationship between familiarity with capital and ability to price and negotiate investments. Journal of Small Business Management 39: 240-258.

Westhead, P., and D.J. Storey. 1997. Financial constraints on the growth of high technology small firms in the United Kingdom. Applied Financial Economics 7: 197-201.

Wiklund, J., and A. Söderblom. 2006. Factors Determining the Performance of Early Stage High Technology Venture Capital Funds: A Review of the Academic Literature. Report to the Small Business Service, UK Department for Trade and Industry.

Williams, M., and C. Cowling. 2009. Annual Small Business Survey 2007/08. Report by the Institute for Employment Studies for the Department for Business Enterprise and Regulatory Reform. Sheffield: BERR Enterprise Directorate.

Wright, M., A. Lockett, B. Clarysse, and M. Binks. 2006. University spin-out companies and venture capital. Research Policy 35: 481-501. 
Table 1: Sectoral distribution of surveyed TBSFs

\begin{tabular}{|l|c|c|c|c|c|c|c|c|}
\hline \multirow{2}{*}{$\begin{array}{l}\text { Sector (Electronic/Bio } \\
\text { science split) }\end{array}$} & \multicolumn{2}{|c|}{$\begin{array}{c}\text { All surveyed } \\
\text { firms }\end{array}$} & \multicolumn{2}{c|}{$\begin{array}{c}\text { Sample 1: } \\
\text { Established firms }\end{array}$} & \multicolumn{2}{c|}{$\begin{array}{c}\text { Sample 2: } \\
\text { Younger firms }\end{array}$} & \multicolumn{3}{c|}{ ABI 2008 } \\
\cline { 2 - 9 } & No. & $\%$ & No. & $\%$ & No. & $\%$ & No. & $\%$ \\
\hline IT software (7/0) & 7 & 7.0 & 3 & 5.9 & 4 & 8.2 & 2,530 & 1.8 \\
\hline IT services (14/0) & 14 & 14.0 & 8 & 15.7 & 6 & 12.2 & 111,268 & 77.7 \\
\hline $\begin{array}{l}\text { Electronic Engineering } \\
\text { (18/0) }\end{array}$ & 18 & 18.0 & 8 & 15.7 & 10 & 20.4 & 5,571 & 3.9 \\
\hline Telecommunication (5/0) & 5 & 5.0 & 3 & 5.9 & 2 & 4.1 & 8,635 & 6.0 \\
\hline $\begin{array}{l}\text { Scientific Instruments/ } \\
\text { Engineering (17/0) }\end{array}$ & 17 & 17.0 & 10 & 19.6 & 7 & 14.3 & 5,194 & 3.6 \\
\hline $\begin{array}{l}\text { Chemical Engineering } \\
\text { (0/4) }\end{array}$ & 4 & 4.0 & 3 & 5.9 & 1 & 2.0 & 567 & 0.4 \\
\hline $\begin{array}{l}\text { Medical/Pharmaceuticals } \\
\text { (0/10) }\end{array}$ & 10 & 10.0 & 7 & 13.7 & 3 & 6.1 & 692 & 0.4 \\
\hline $\begin{array}{l}\text { Research and } \\
\text { Development (0/22) }\end{array}$ & 22 & 22.0 & 7 & 13.7 & 15 & 30.6 & 4,571 & 3.2 \\
\hline $\begin{array}{l}\text { Consultancy/Business } \\
\text { Support (1/2) }\end{array}$ & 3 & 3.0 & 2 & 3.9 & 1 & 2.0 & 4,178 & 3.0 \\
\hline Total & 100 & 100 & 51 & 100 & 49 & 100 & 143,206 & 100 \\
\hline
\end{tabular}

Note: UK Annual Business Inquiry ( $\mathrm{ABI}) 2008$ data refers to numbers of pay units as proxies for businesses

Digital Electronic/IT sectors (SIC2003): 3001/2 Office and Computers; 3110 Electrical motors; 3120 Electrical controls; 3210 Electrical components; 3220 TV and Radio; 3320 Measuring devices; 3330 Process controls; 3340 Optical; 3530 Aircraft; 6420 Telecomms; 7210 Hardware consultancy; 7221/2 Publishing software; 7230/40 Data; 7260 Other computing

Bio/Life science sectors (SIC2003): 2416/7 Plastics; 2441/2 Pharmaceuticals; 3310 Medical; 7310/20 $R \& D$ consultancy 
Table 2: Interviewed finance providers

\begin{tabular}{|l|c|}
\hline Type & Frequency \\
\hline Private VCs & 3 \\
\hline Public VCs & 2 \\
\hline Mezzanine fund managers & 3 \\
\hline Business angels & 6 \\
\hline Bankers & 3 \\
\hline Grants & 1 \\
\hline TBSF sector experts/facilitators & 2 \\
\hline Total & $\mathbf{2 0}$ \\
\hline
\end{tabular}


Table 3: Growth orientation and constraints of surveyed TBSFs

\begin{tabular}{|l|c|c|c|c|c|c|}
\hline & \multicolumn{2}{|c|}{ All TBSFs $\mathbf{( n = 1 0 0 )}$} & \multicolumn{2}{c|}{$\begin{array}{c}\text { Established TBSFs } \\
(\mathbf{n}=\mathbf{5 1})\end{array}$} & \multicolumn{2}{c|}{ Younger TBSFs (n=49) } \\
\hline Growth orientation & No. & $\%$ & No. & $\%$ & No. & $\%$ \\
\hline Growth & 67 & 67 & 33 & 64.7 & 34 & 69.4 \\
\hline Survival & 15 & 15 & 10 & 19.6 & 5 & 10.2 \\
\hline No need & 8 & 8 & 6 & 11.8 & 2 & 4.1 \\
\hline Not ready & 10 & 10 & 2 & 3.9 & 8 & 16.3 \\
\hline Constraints & & & & & & \\
\hline None & 14 & 14 & 8 & 15.7 & 6 & 12.2 \\
\hline Finance & 24 & 24 & 11 & 21.6 & 13 & 26.5 \\
\hline Lack of demand & 34 & 34 & 19 & 37.3 & 15 & 30.6 \\
\hline Workforce & 8 & 8 & 8 & 15.7 & 0 & 0 \\
\hline Management time & 6 & 6 & 3 & 5.9 & 3 & 6.1 \\
\hline Technical barriers & 6 & 6 & 3 & 5.9 & 3 & 6.1 \\
\hline Trade regulations & 3 & 3 & 1 & 2 & 2 & 4.1 \\
\hline Premises & 3 & 3 & 0 & 0 & 3 & 6.1 \\
\hline Sales \& marketing & 5 & 5 & 0 & 0 & 5 & 10.2 \\
\hline
\end{tabular}

Note: 3 cases mentioned two main constraints 
Table 4: Growth characteristics of surveyed TBSFs

\begin{tabular}{|c|c|c|c|c|c|c|c|}
\hline \multicolumn{5}{|c|}{ (a) Number of Employees } & \multicolumn{3}{|c|}{ (b) Sales Turnover } \\
\hline \multicolumn{8}{|c|}{ All Firms } \\
\hline Change & \multicolumn{2}{|c|}{ Employment } & No. & $\%$ & $\begin{array}{c}\text { Sales } \\
\text { Turnover }\end{array}$ & No. & $\%$ \\
\hline $2007-10$ & \multicolumn{2}{|l|}{ Increased } & 45 & 49 & Increased & 46 & 59 \\
\hline $2007-10$ & \multicolumn{2}{|l|}{ Stable } & 34 & 37 & Stable & 10 & 13 \\
\hline \multirow[t]{2}{*}{$2007-10$} & \multicolumn{2}{|l|}{ Decreased } & 13 & 14 & Decreased & 22 & 28 \\
\hline & & & \multicolumn{2}{|c|}{ Established Firms } & & & \\
\hline 2007-10 & \multicolumn{2}{|l|}{ Increased } & 25 & 49 & Increased & 23 & 54 \\
\hline $2007-10$ & \multicolumn{2}{|l|}{ Stable } & 17 & 33 & Stable & 6 & 14 \\
\hline \multirow[t]{2}{*}{$2007-10$} & \multicolumn{2}{|l|}{ Decreased } & 9 & 18 & Decreased & 14 & 33 \\
\hline & & & \multicolumn{2}{|c|}{ Younger Firms } & & & \\
\hline $2007-10$ & \multicolumn{2}{|l|}{ Increased } & 20 & 48 & Increased & 23 & 66 \\
\hline $2007-10$ & \multicolumn{2}{|l|}{ Stable } & 17 & 42 & Stable & 4 & 11 \\
\hline \multirow[t]{2}{*}{$2007-10$} & \multicolumn{2}{|l|}{ Decreased } & 4 & 10 & Decreased & 8 & 23 \\
\hline & $\begin{array}{c}\text { Full-time } \\
\text { mean }\end{array}$ & $\begin{array}{l}\text { Part-time } \\
\text { mean }\end{array}$ & \multicolumn{2}{|c|}{$\begin{array}{c}\text { All Firms }(\mathrm{n}=92) \\
\text { mean }\end{array}$} & & mean & median \\
\hline 2007 & 9.1 & 0.9 & 10.1 & 4 & 2006-07 & $£ 1,138,700$ & $£ 300,000$ \\
\hline 2010 & 12.2 & 1.2 & 13.3 & 5.5 & $2009-10$ & $£ 1,625,200$ & $£ 500,000$ \\
\hline 2011 & 13.8 & 1.2 & 15 & 7 & 2010-11 & $£ 1,946,700$ & $£ 500,000$ \\
\hline \multicolumn{8}{|c|}{ Established Firms $(n=51)$} \\
\hline & Full-time & Part-time & \multicolumn{2}{|c|}{ Total } & & & \\
\hline 2007 & 13.5 & 1.1 & 14.5 & 5 & 2006-07 & $£ 1,840,300$ & $£ 600,000$ \\
\hline 2010 & 16.8 & 1.4 & 18.3 & 6 & 2009-10 & $£ 2,490,000$ & $£ 824,000$ \\
\hline 2011 & 18.4 & 1.5 & 19.9 & 8 & 2010-11 & $£ 2,931,800$ & $£ 1,000,000$ \\
\hline \multicolumn{8}{|c|}{ Younger Firms $(n=41)$} \\
\hline & Full-time & Part-time & \multicolumn{2}{|c|}{ Total } & & & \\
\hline 2007 & 3.7 & 0.8 & 4.6 & 3 & 2006-07 & $£ 292,600$ & $£ 106,000$ \\
\hline 2010 & 6.3 & 0.8 & 7.2 & 4 & 2009-10 & $£ 582,400$ & $£ 230,000$ \\
\hline 2011 & 8 & 0.8 & 8.9 & 6 & 2010-11 & $£ 758,800$ & $£ 400,000$ \\
\hline
\end{tabular}

Note: Employee data: Established firms $\mathrm{n}=51$; Younger firms $\mathrm{n}=41$ (8 TBSFs not established prior to 2007)

Sales turnover data: $n=75$ (established $n=41$, younger $n=34$ ) where complete data for each year represented (78 had complete data for 2007 and 2010 and 75 for 2007, 2010 and 2011) 
Table 5: Funding for the surveyed TBSFs in the last 3 years

\begin{tabular}{|c|c|c|}
\hline All TBSFs & No of firms & Percentage \\
\hline Internal sources (e.g. Ploughing back profits, personal funding) & 81 & 81 \\
\hline Informal external sources (e.g. Family and friends) & 6 & 6 \\
\hline Formal external sources (e.g. Banks, VC funds, public sector grants) & 53 & 53 \\
\hline \multicolumn{3}{|l|}{ Established TBSFs } \\
\hline Internal sources (e.g. Ploughing back profits, personal funding) & 44 & 86 \\
\hline Informal external sources (e.g. Family and friends) & 1 & 2 \\
\hline Formal external sources (e.g. Banks, VC funds, public sector grants) & 26 & 52 \\
\hline \multicolumn{3}{|l|}{ Younger TBSFs } \\
\hline Internal sources (e.g. Ploughing back profits, personal funding) & 37 & 75 \\
\hline Informal external sources (e.g. Family and friends) & 5 & 10 \\
\hline Formal external sources (e.g. Banks, VC funds, public sector & 27 & 55 \\
\hline
\end{tabular}

Note: Some businesses used more than one source 
Table 6a: Binary Logistic Analysis for those TBSFs Seeking External Finance (dependent variable)

\begin{tabular}{|c|c|c|c|c|c|c|c|c|}
\hline Model 1: & \multicolumn{2}{|c|}{ 1. All TBSFs } & \multicolumn{2}{|c|}{$\begin{array}{l}\text { 2. Trading } \\
\text { (sales) TBSFs }\end{array}$} & \multicolumn{2}{|c|}{ 3. Bank Finance } & \multicolumn{2}{|c|}{$\begin{array}{l}\text { 4. Equity } \\
\text { Finance }\end{array}$} \\
\hline $\begin{array}{l}\text { Independent } \\
\text { variable }\end{array}$ & B & Sig. & $B$ & Sig. & $B$ & Sig. & B & Sig. \\
\hline Bio/Life science & .733 & .097 & 1.335 & .022 & .524 & .227 & 1.338 & .010 \\
\hline Innovation change & -.596 & .212 & -.467 & .420 & -.546 & .250 & -.166 & .780 \\
\hline Credit crunch & .165 & .770 & -.189 & .781 & -.050 & .927 & .993 & .096 \\
\hline $\begin{array}{l}\text { Established 5+ } \\
\text { years }\end{array}$ & 152 & .747 & .519 & .518 & -.402 & .387 & -.457 & .433 \\
\hline Sales up & $\mathrm{n} / \mathrm{a}$ & $\mathrm{n} / \mathrm{a}$ & .105 & .889 & $\mathrm{n} / \mathrm{a}$ & $\mathrm{n} / \mathrm{a}$ & $n / a$ & $\mathrm{n} / \mathrm{a}$ \\
\hline High growth & $\mathrm{n} / \mathrm{a}$ & $\mathrm{n} / \mathrm{a}$ & -.003 & .997 & $\mathrm{n} / \mathrm{a}$ & $\mathrm{n} / \mathrm{a}$ & $\mathrm{n} / \mathrm{a}$ & $\mathrm{n} / \mathrm{a}$ \\
\hline Profit up & $\mathrm{n} / \mathrm{a}$ & $\mathrm{n} / \mathrm{a}$ & 201 & .731 & $\mathrm{n} / \mathrm{a}$ & $\mathrm{n} / \mathrm{a}$ & $\mathrm{n} / \mathrm{a}$ & $\mathrm{n} / \mathrm{a}$ \\
\hline Spinout & .534 & 269 & .395 & .502 & 302 & .522 & .111 & .852 \\
\hline Growth aim & -.510 & .281 & -.765 & .221 & .230 & .621 & -1.024 & .060 \\
\hline Constant & .124 & .810 & -.012 & .986 & -.164 & .747 & -1.090 & .073 \\
\hline $\mathrm{N}=$ & \multicolumn{2}{|l|}{100} & \multicolumn{2}{|l|}{78} & \multicolumn{2}{|l|}{100} & \multicolumn{2}{|l|}{100} \\
\hline $\begin{array}{l}\text { Nagelkerke R } \\
\text { square }\end{array}$ & \multicolumn{2}{|l|}{.110} & \multicolumn{2}{|l|}{.186} & \multicolumn{2}{|l|}{.075} & \multicolumn{2}{|l|}{.250} \\
\hline -2 Log Likelihood & \multicolumn{2}{|c|}{129.643} & \multicolumn{2}{|l|}{95.633} & \multicolumn{2}{|l|}{132.481} & \multicolumn{2}{|l|}{93.266} \\
\hline
\end{tabular}

Note: Bio/life science as opposed to Electronics/IT

Innovation change in business taken place in period 2007-10

Performance affected by credit crunch

Business performance real terms improvement (sales, profits) 2007-10

High growth where at least $50 \%$ increase in sales

Table 6b: Binary Logistic Analysis for those TBSFs Receiving External Finance (dependent variable)

\begin{tabular}{|c|c|c|c|c|c|c|}
\hline Model 2a: & \multicolumn{2}{|c|}{$\begin{array}{l}\text { 2. Trading } \\
\text { (sales) }\end{array}$} & \multicolumn{2}{|c|}{ 3. Bank Finance } & \multicolumn{2}{|c|}{$\begin{array}{l}\text { 4. Equity } \\
\text { Finance }\end{array}$} \\
\hline $\begin{array}{l}\text { Independent } \\
\text { variable }\end{array}$ & $B$ & Sig. & $B$ & Sig. & $B$ & Sig. \\
\hline Bio/Life science & 2.846 & .000 & 1.450 & .014 & 4.626 & .010 \\
\hline Innovation change & -.190 & .763 & -.928 & .119 & 2.657 & .124 \\
\hline Credit crunch & -.112 & .880 & -.269 & .698 & -.832 & .611 \\
\hline $\begin{array}{l}\text { Established 5+ } \\
\text { years }\end{array}$ & -.875 & 176 & -.877 & .146 & -3.015 & .088 \\
\hline Sales up & -.818 & .219 & -.415 & .500 & -2.992 & .097 \\
\hline High growth & -.415 & .540 & .813 & .200 & -1.459 & .300 \\
\hline Profit up & -.923 & 292 & -.323 & .705 & 1.938 & 1.000 \\
\hline Spinout & 071 & .931 & -.433 & .590 & 19.881 & .998 \\
\hline Growth aim & .655 & .429 & .553 & .506 & .020 & .993 \\
\hline Constant & 841 & .285 & -.410 & .556 & -23.19 & .996 \\
\hline $\mathrm{N}=$ & \multicolumn{2}{|l|}{78} & \multicolumn{2}{|l|}{78} & \multicolumn{2}{|l|}{78} \\
\hline $\begin{array}{l}\text { Nagelkerke R } \\
\text { square }\end{array}$ & \multicolumn{2}{|l|}{.353} & \multicolumn{2}{|l|}{.233} & \multicolumn{2}{|l|}{.684} \\
\hline -2 Log Likelihood & \multicolumn{2}{|l|}{83.042} & \multicolumn{2}{|l|}{90.061} & \multicolumn{2}{|l|}{20.221} \\
\hline
\end{tabular}


Table 6c: Binary Logistic Analysis for those TBSFs Receiving External Finance (dependent variable) including Stage and Round of Finance

\begin{tabular}{|c|c|c|c|c|c|c|}
\hline \multirow{2}{*}{$\begin{array}{l}\text { Model 2b: } \\
\text { Independent } \\
\text { variable }\end{array}$} & \multicolumn{2}{|c|}{ 1. All Seekers } & \multicolumn{2}{|c|}{ 2. Bank Finance } & \multicolumn{2}{|c|}{$\begin{array}{l}\text { 3. Equity } \\
\text { Finance }\end{array}$} \\
\hline & $\mathrm{B}$ & Sig. & $\mathrm{B}$ & Sig. & $B$ & Sig. \\
\hline Innovation change & 1.365 & .254 & .051 & .946 & 1.116 & .275 \\
\hline Credit crunch & 1.843 & .170 & -.350 & .674 & -.648 & .553 \\
\hline $\begin{array}{l}\text { Established 5+ } \\
\text { years }\end{array}$ & -1.818 & .124 & -2.287 & .013 & -.313 & .765 \\
\hline Spinout & -2.424 & .033 & -1.794 & .030 & .219 & .829 \\
\hline Growth aim & .412 & .686 & 1.677 & .021 & -.189 & 861 \\
\hline Bio/Life science & 1.005 & .279 & .595 & .388 & .833 & .412 \\
\hline Early stage & -2.017 & .073 & -2.631 & .002 & -1.354 & .233 \\
\hline Early round & .023 & .984 & .827 & .312 & -2.719 & .017 \\
\hline Constant & 3.409 & .048 & .760 & .436 & -.740 & .530 \\
\hline $\mathrm{N}=$ & \multicolumn{2}{|l|}{66} & \multicolumn{2}{|l|}{66} & \multicolumn{2}{|l|}{66} \\
\hline $\begin{array}{l}\text { Nagelkerke R } \\
\text { square }\end{array}$ & \multicolumn{2}{|l|}{.312} & \multicolumn{2}{|l|}{.468} & \multicolumn{2}{|l|}{.319} \\
\hline -2 Log Likelihood & \multicolumn{2}{|l|}{39.964} & \multicolumn{2}{|l|}{62.005} & \multicolumn{2}{|l|}{39.689} \\
\hline
\end{tabular}

Note: Early stage refers to seed and early stage R\&D funding

Early round refers to first round funding

Table 6d: Binary Logistic Analysis for those TBSFs where Difficulties Obtaining External Finance Affected Business Performance (dependent variable)

\begin{tabular}{|c|c|c|c|c|c|c|}
\hline Model 3: & \multicolumn{2}{|c|}{ 1. All Seekers } & \multicolumn{2}{|c|}{$\begin{array}{l}\text { 2. Trading } \\
\text { (sales) }\end{array}$} & \multicolumn{2}{|c|}{ 3. Trading/Finance } \\
\hline $\begin{array}{l}\text { Independent } \\
\text { variable }\end{array}$ & $\mathrm{B}$ & Sig. & $\mathrm{B}$ & Sig. & $\mathrm{B}$ & Sig. \\
\hline Innovation change & -.568 & .281 & -.781 & .226 & -.152 & 892 \\
\hline Credit crunch & 1.133 & .048 & 1.208 & .088 & 1.824 & .103 \\
\hline $\begin{array}{l}\text { Established 5+ } \\
\text { years }\end{array}$ & 249 & .629 & .562 & 391 & 1.491 & .118 \\
\hline Spinout & 1.155 & .025 & 1.300 & .041 & 1.779 & .068 \\
\hline Growth aim & -.351 & .485 & .019 & .976 & -.142 & .873 \\
\hline Bio/Life science & .356 & .441 & .378 & .525 & -.294 & .716 \\
\hline Sales up & $\mathrm{n} / \mathrm{a}$ & $n / a$ & -2.121 & .080 & -3.272 & .138 \\
\hline High growth & n/a & $n / a$ & 1.917 & .120 & .889 & .565 \\
\hline Profit up & $\mathrm{n} / \mathrm{a}$ & $\mathrm{n} / \mathrm{a}$ & .157 & .877 & 1.630 & .326 \\
\hline Bank finance & $\mathrm{n} / \mathrm{a}$ & $\mathrm{n} / \mathrm{a}$ & $\mathrm{n} / \mathrm{a}$ & $\mathrm{n} / \mathrm{a}$ & 4.565 & .002 \\
\hline Equity finance & $\mathrm{n} / \mathrm{a}$ & $\mathrm{n} / \mathrm{a}$ & $\mathrm{n} / \mathrm{a}$ & $\mathrm{n} / \mathrm{a}$ & 2.161 & .051 \\
\hline Constant & -1.088 & .056 & -1.307 & .092 & -5.665 & .001 \\
\hline $\mathrm{N}=$ & \multicolumn{2}{|l|}{100} & \multicolumn{2}{|l|}{78} & \multicolumn{2}{|l|}{78} \\
\hline $\begin{array}{l}\text { Nagelkerke R } \\
\text { square }\end{array}$ & \multicolumn{2}{|l|}{.187} & \multicolumn{2}{|l|}{.278} & \multicolumn{2}{|l|}{.676} \\
\hline -2 Log Likelihood & \multicolumn{2}{|l|}{116.055} & \multicolumn{2}{|l|}{81.876} & \multicolumn{2}{|l|}{47.220} \\
\hline
\end{tabular}


Table 7: Formal external funding sources approached 2007-10 and outcomes

\begin{tabular}{|c|c|c|c|}
\hline Source & $\begin{array}{l}\text { Approached } \\
\text { No }\left(\% \text { of } n^{\star}\right)\end{array}$ & \begin{tabular}{|l|} 
Success \\
Rate*** \\
(Row \%) \\
\end{tabular} & Outcome \\
\hline $\begin{array}{l}\text { Bank overdraft } \\
\text { All TBSFs } \\
\text { Established } \\
\text { Younger }\end{array}$ & $\begin{array}{l}36(36 \%) \\
16(32 \%) \\
20(40 \%)\end{array}$ & $\begin{array}{l}81 \% \\
81 \% \\
80 \%\end{array}$ & $\begin{array}{l}\text { Successful: 26; Unsuccessful: 7; Partial: } 3 \\
\text { Successful: 13; Unsuccessful: 3; } \\
\text { Successful: 13; Unsuccessful: 4; Partial: } 3\end{array}$ \\
\hline $\begin{array}{l}\text { Bank loan } \\
\text { All TBSFs } \\
\text { Established } \\
\text { Younger }\end{array}$ & $\begin{array}{l}25(25 \%) \\
8(16 \%) \\
17(34 \%)\end{array}$ & $\begin{array}{l}58 \% \\
43 \% \\
65 \%\end{array}$ & $\begin{array}{l}\text { Successful: } 13 \text { (9 taken up); Partial: } 1 \\
\text { Unsuccessful: } 10 ; \text { Pending: } 1 \\
\text { Successful: } 3 \text { (3 taken up); Unsuccessful: } 4 \text {; } \\
\text { Pending: } 1 \\
\text { Successful: } 10 \text { (6 taken up); Partial: } 1 \\
\text { Unsuccessful: } 6\end{array}$ \\
\hline $\begin{array}{l}\text { Venture capital } \\
\text { fund } \\
\text { All TBSFs } \\
\text { Established } \\
\text { Younger }\end{array}$ & $\begin{array}{l}12(12 \%) \\
7(14 \%) \\
5(10 \%)\end{array}$ & $\begin{array}{l}64 \% \\
57 \% \\
75 \%\end{array}$ & $\begin{array}{l}\text { Successful: } 7 \text { (6 taken up); Unsuccessful: 4; } \\
\text { Pending: } 1 \\
\text { Successful: } 4 \text { (3 taken up); Unsuccessful: } 3 \\
\text { Successful: 3; Unsuccessful: 1; Pending: } 1\end{array}$ \\
\hline $\begin{array}{l}\text { Business angels } \\
\text { All TBSFs } \\
\text { Established } \\
\text { Younger }\end{array}$ & $\begin{array}{c}14(14 \%) \\
4(8 \%) \\
10(20 \%)\end{array}$ & $\begin{array}{l}46 \% \\
33 \% \\
50 \%\end{array}$ & $\begin{array}{l}\text { Successful: 6; Unsuccessful: } 7 \text { Pending:1 } \\
\text { Successful: 1; Unsuccessful: 2; Pending: } 1 \\
\text { Successful: } 5 \text { (3 taken up); Unsuccessful: } 5\end{array}$ \\
\hline $\begin{array}{l}\text { Public sector } \\
\text { grant / award } \\
\text { All TBSFs } \\
\text { Established } \\
\text { Younger }\end{array}$ & $\begin{array}{l}25(25 \%) \\
10(20 \%) \\
15(30 \%)\end{array}$ & $\begin{array}{l}96 \% \\
90 \% \\
100 \%\end{array}$ & $\begin{array}{l}\text { Successful: 22; Partial: 2; Unsuccessful: } 1 \\
\text { Successful: 8; Partial: 1; Unsuccessful: } 1 \\
\text { Successful: 14; Partial: } 1\end{array}$ \\
\hline
\end{tabular}

